JURNAL 『ERKNOSAINS

VOLUME 1

No. 1, 22 Desember 2011

Halaman 1-69

\title{
KAJIAN METODE DETEKSI DEGRADASI HUTAN MENGGUNAKAN CITRA SATELIT LANDSAT DI HUTAN LAHAN KERING TAMAN NASIONAL HALIMUN SALAK
}

\author{
Sigit Nugroho \\ Staf Ditjen Planologi Kehutanan Kementerian Kehutanan \\ Email: sigit_nugroho_ssi@yahoo.com \\ I Nengah Surati Jaya dan M. Buce Saleh \\ Staf Pengajar di Institut Pertanian Bogor Kampus Darmaga \\ Antonius B Wijanarto \\ Staf Pengajar Bakosurtanal Cibinong Bogor
}

\begin{abstract}
The study examined detection method of forest degradation using forest canopy density (FCD), maximum likelihood, fuzzy and belief dempster shafer classification method. Accuracy evaluation of classification and detection were based on overall accuracy which obtained from 51 ground sample plot. Canopy density, LAI, crown indicator, trees density and basal area (Lbds) were conducted as field indicators. Accuracy of classification among forest density (trees/Ha) with four classification methods were FCD 61\%, maximum likelihood 57\%, fuzzy 51\% and belief dempster shafer 49\%. Based on temporal detection accuracy from 2003 until 2008, FCD had overall accuracy $68 \%$. The result of research, FCD is the best method to detect of forest degradation.
\end{abstract}

Keywords: detection method, forest degradation, Landsat.

\begin{abstract}
ABSTRAK
Studi ini mengkaji metode deteksi degradasi hutan menggunakan metode klasifikasi forest canopy density(FCD), maximum likelihood, fuzzy, dan belief dempster shafer. Uji akurasi klasifikasi dan deteksi menggunakan overall accuracy yang didapatkan dari 51 sampel lapangan. Kerapatan kanopi, leaf area index (LAI), indikator tajuk, kerapatan pohon, dan luas bidang dasar (lbds) digunakan sebagai indikator degradasi di lapangan. Hasil uji akurasi klasifikasi antara hasil klasifikasi dengan kerapatan pohon adalah FCD 61\%, maximum likelihood 57\%, fuzzy 51\%, dan belief dempster shafer $49 \%$. Berdasarkan deteksi degradasi secara temporal dari tahun 2003 sampai 2008, FCD mempunyai akurasi 68 \%. Hasil penelitian ini, FCD adalah metode terbaik untuk deteksi degradasi hutan.
\end{abstract}

Kata kunci: metode deteksi, degradasi hutan, Landsat. 
SIGIT NUGROHO, I NENGAH SURATI JAYA, M BUCE SALEH, ANTONIUS B WIJANARTO KAJIAN METODE DETEKSI DEGRADASI HUTAN MENGGUNAKAN CITRA SATELIT LANDSAT DI ...

\section{PENGANTAR}

Indonesia merupakan salah satu negara yang mempunyai hutan tropis terbesar di dunia. Pada tahun 2003 - 2006, kondisi laju deforestasi mencapai angka 1,1 Juta Ha pertahun (DEPHUT 2008). Data FAO (2005), angka deforestasi Indonesia pada tahun 20002005 mencapai 1,9 juta Ha pertahun. COP 13 UNFCC telah mengakomodasi pentingnya degradasi hutan untuk mengurangi emisi melalui Reducing Emissions from Deforestation and Forest Degradation/REDD (Murdiarso et al., 2008). Unsur degradasi hutan dalam mekanisme REDD mempunyai dampak positif dalam adaptasi perubahan iklim.

Degradasi hutan merupakan suatu proses yang sulit dideteksi karena melibatkan proses penurunan kualitas kanopi hutan dan struktur vertikal kanopi hutan dengan jangka waktu yang lama (Panta et al., 2008). Menurut Penman et al., (2003) untuk mendapatkan prosedur operasional monitoring, reporting, and verification (MRV) tentang degradasi hutan masih menjadi masalah yang krusial. Sistem pemantauan yang komprehensif akan dapat menghasilkan data dan indikator tutupan hutan yang lebih baik, guna menampung kebutuhan informasi terkini bagi pesatnya perkembangan proses REDD (Kanninen et al., 2009).

Metode deteksi menggunakan data penginderaan jauh telah digunakan untuk menilai kerapatan kanopi hutan sebagai indikator degradasi hutan (Hadi et al., 2004; Joshi et al., 2006). Penggunaan persentase kerapatan kanopi menggunakan citra satelit Landsat untuk deteksi degradasi menghasilkan akurasi yang tinggi dan sangat menjanjikan (Panta et al,. 2008; Hwan dan Merlinda, 2008).

Deteksi degradasi menggunakan data penginderaan jauh memiliki tantangan teknis yang lebih besar daripada memantau deforestasi (Defries et al., 2007). Data penginderaan jauh yang didukung oleh observasi di lapangan merupakan kunci pemantauan yang efektif dan efisien
(Kanninen et al., 2009). Kebutuhan data untuk MRV pada mekanisme REDD sangat diperlukan pada kawasan konservasi yaitu Taman Nasional Halimun Salak (TNHS).

Metode pemantauan degradasi hutan menggunakan data penginderaan jauh untuk tujuan MRV masih membutuhkan sebuah metode yang baik untuk diaplikasikan (Murdiarso et al., 2008; Bahamondez et al., 2009). Metode pemantauan menggunakan teknologi penginderaan jauh adalah dengan metode change detection. Klasifikasi citra dalam metode change detection yang digunakan adalah forest canopy density, maximum likelihood, fuzzy, dan belief dempster shafer. Metode-metode tersebut memerlukan kajian untuk dapat diterapkan di hutan lahan kering di Taman Nasional Halimun Salak yang mempunyai karakteristik yang spesifik. Tujuan penelitian ini adalah membangun metode yang tepat untuk deteksi degradasi hutan di TNHS.

Lokasi penelitian ini adalah di kawasan hutan Gunung Surandil dan Gunung Pangkulahan Taman Nasional Halimun Salak. Penelitian dimulai dari bulan Juli 2010 sampai Desember 2010. Sumber data yang digunakan dalam penelitian ini adalah citra digital Landsat TM tahun 2003, 2007, 2008, dan citra Quickbird tahun 2006.

Alat yang digunakan dalam penelitian ini seperangkat komputer dan perangkat lunak ARC View 3.3 Envi v 4.1, Idrisi, FCD Mapper Versi 2. Seperangkat alat untuk pengukuran di lapangan: GPS, Kompas, diameter tape, roll meter, stasioner, tally sheet, dan kamera fisheye.

Prosedur penelitian ini terdiri dari tahap persiapan alat, kerja laboratorium penginderaan jauh dan SIG, kerja lapangan, uji akurasi, dan pembuatan laporan hasil penelitian. Pada pengolahan citra yang dilakukan adalah mengolah citra Landsat tahun 2003,2007 dan 2008 untuk menghasilkan kelas kerapatan hutan dengan menggunakan empat metode klasifikasi. Proses pembuatan FCD menggunakan software FCD-Mapper 
Ver. 2. Untuk lebih lengkapnya dapat dilihat pada Gambar 1.

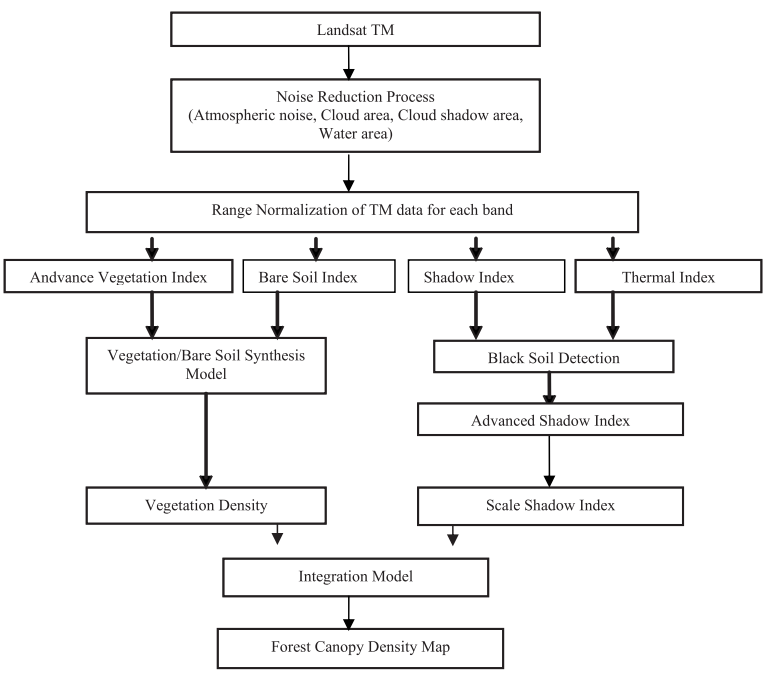

Gambar 1.

Proses Klasifikasi Forest Canopy Density

(Rikimaru, 2003)

Klasifikasi maximum likelihood adalah salah satu dari klasifikasi terbimbing. Algoritma yang digunakan dalam penentuan klasifikasi ini adalah dengan menggunakan metode maximum likelihood. Metode klasifikasi fuzzy mempertimbangkan piksel-piksel yang bercampur (mixed make-up) dimana suatu piksel tidak dapat dikelaskan secara definitif ke satu kelas. Klasifikasi ini bekerja dengan suatu fungsi keanggotaan dimana piksel tersebut ditentukan apakah lebih dekat ke satu kelas atau kelas lainnya. Output dari metode ini tidaklah peta tunggal tutupan lahan, tetapi merupakan satu set peta (per kelas) yang menyatakan tingkat fungsi keanggotaan pada masing-masing kelas.

Klasifikasi belief (Belclas) adalah suatu proses pengambilan keputusan tentang keanggotaan kelas pada suatu piksel untuk masuk ke suatu kelompok tingkat keanggotaan pada setiap kelas yang mungkin. Seperti prosedur klasifikasi terbimbing, penggunaan training area tetap dibutuhkan untuk mengklasifikasikan setiap piksel. Output metode ini bukan peta tunggal tutupan lahan, tetapi merupakan satu set peta (per kelas) yang menyatakan aspek kepercayaan maupun tingkat masuk akal piksel untuk masuk pada masing-masing kelas.

Desain sampel yang digunakan dalam penelitian ini adalah stratified purposive sampling. Jumlah sampel pada penelitian ini adalah 51 sampel. Strata sampel plot yang diambil berdasarkan kelas kerapatan hutan yang dihasilkan dan jumlahnya tiap strata disesuaikan dengan nilai sampel totalnya $(\mathrm{N})$.

Ukuran plot di lapangan dengan menggunakan citra beresolusi 20-30 meter adalah dengan ukuran $50 \times 50$ meter. Pengambilan data tegakan pada diameter 5-10 cm dan 10 - $20 \mathrm{~cm}$ dikuadran I. Luas untuk pengambilan sampel $5-10 \mathrm{~cm}$ adalah $5 \times 5 \mathrm{~m}$, sedangkan luas untuk pengambilan sampel $10-20 \mathrm{~cm}$ adalah $10 \times 10 \mathrm{~m}$ dari titik pusat plot. Data tegakan diameter $>20 \mathrm{~cm}$ diambil pada semua kuadran dengan ukuran $25 \times 25 \mathrm{~m}$.

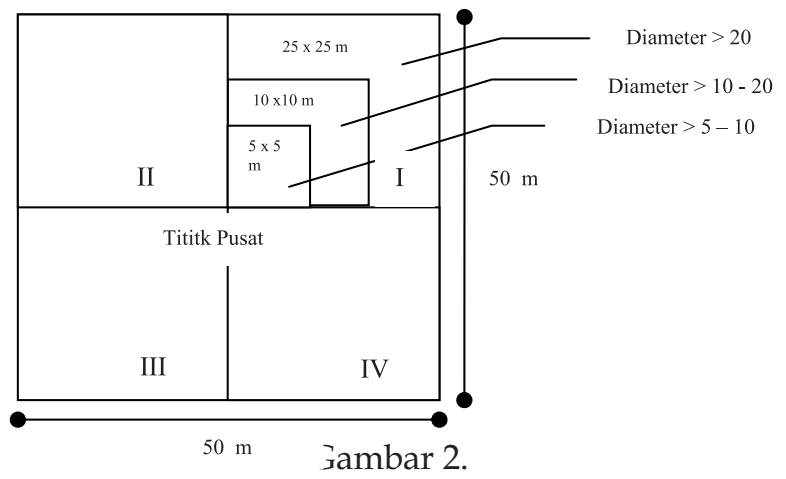

Desain Sampel Plot di Lapangan

Hasil metode klasifikasi kerapatan hutan dengan citra Landsat akurasinya diuji dengan data kerapatan kanopi, kerapatan pohon, Crown Size Index (CSI), Crown Damage Index (CDI), Visual Crown Rating (VCR), Leaf Area Index (LAI), dan luas bidang dasar (Lbds). Uji hasil klasifikasi kerapatan hutan dan degradasi hutan menggunakan user's accuracy, producer's accuracy dan overall accuracy, dan analisis Kappa. Nilai akurasi sedang adalah $60-85 \%$ dan tinggi adalah $>85 \%$. 
SIGIT NUGROHO, I NENGAH SURATI JAYA, M BUCE SALEH, ANTONIUS B WIJANARTO KAJIAN METODE DETEKSI DEGRADASI HUTAN MENGGUNAKAN CITRA SATELIT LANDSAT DI ...

Diagram alir penelitian ini dapat dilihat pada Gambar 3. Diagram alir dimulai dari proses pengolahan data, analisis, dan hasil penelitian.

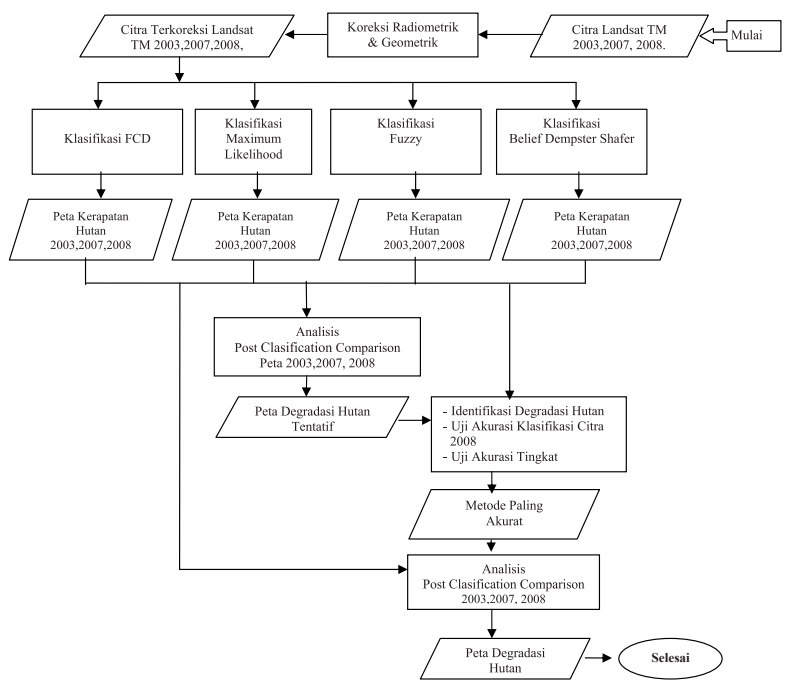

Gambar 3.

Diagram Alir Penelitian

\section{PEMBAHASAN}

Penentuan indikator untuk identifikasi degradasi hutan di lapangan adalah dengan menggunakan analisis regresi pada masing-masing peubah di lapangan. Identifikasi pendugaan degradasi hutan menggunakan dua pendekatan yaitu dengan pendekatan pohon yang masih hidup (pohon sisa) dan pohon yang telah mati (akibat mati alami atau ditebang).

Berdasarkan analisis regresi antara peubah kerapatan pohon yang mati dilapangan dan luas bidang dasarnya (lbds) dengan peubah lainnya maka hasilnya dapat dilihat pada Tabel 1. Hasil koefisien determinasi menunjukkan bahwa nilai koefisien determinasinya rendah pada semua peubah. Kesimpulannya bahwa kerapatan pohon yang mati tidak mempengaruhi variasi perubahan indikator kanopi dari pohon sisa (LAI,CSI, CDI, VCR, dan kerapatan kanopi). Hal ini disebabkan kurun waktu yang terlalu lama dari mulai pohon ditebang dengan pengambilan data di lapangan sehingga pada kurun waktu yang lama tersebut telah terjadi recovery dari tajuk pohon lain.

Tabel 1.

Hasil Analisis Regresi antara Kerapatan Tegakan Mati dan Luas Bidang Dasar dengan Peubah LAI, CSI, CDI, VCR, dan Kerapatan Kanopi

\begin{tabular}{|c|c|c|c|c|c|c|c|}
\hline \multirow{3}{*}{ No } & \multirow{3}{*}{ Peubah } & \multicolumn{6}{|c|}{ Koefisien Determinasi } \\
\hline & & \multicolumn{3}{|c|}{ Kerapatan Tegakan } & \multicolumn{3}{|c|}{ Lbds } \\
\hline & & $\begin{array}{c}\text { Diameter } \\
>5 \mathrm{~cm}\end{array}$ & $\begin{array}{c}\text { Diameter } \\
>10 \mathrm{~cm}\end{array}$ & $\begin{array}{c}\text { Diameter } \\
>20 \mathrm{~cm}\end{array}$ & $\begin{array}{l}\text { Diameter } \\
>5 \mathrm{~cm}\end{array}$ & $\begin{array}{c}\text { Diameter } \\
>10 \mathrm{~cm}\end{array}$ & $\begin{array}{c}\text { Diameter } \\
>20 \mathrm{~cm}\end{array}$ \\
\hline 1 & LAI & 0.21 & 0.06 & 0.05 & 0.1 & 0.07 & 0.06 \\
\hline 2 & CSI & 0.40 & 0.16 & 0.04 & 0.05 & 0.02 & 0.00 \\
\hline 3 & CDI & 0.29 & 0.16 & 0.07 & 0.00 & 0.00 & 0.00 \\
\hline 4 & VCR & 0.41 & 0.17 & 0.06 & 0.02 & 0.00 & 0.00 \\
\hline 5 & Kerapatan Kanopi & 0.38 & 0.20 & 0.10 & 0.03 & 0.01 & 0.01 \\
\hline
\end{tabular}


Pada penelitian dilakukan analisis regresi antara peubah tajuk dengan kerapatan tegakan yang tersisa dan luas bidang dasarnya untuk mengidentifikasi perubahan variasi perubahan kerapatan tegakan dan lbds. Berdasarkan analisis regresi antara peubah kerapatan tegakan yang tersisa di lapangan dan luas bidang dasar dengan peubah lainnya, maka hasilnya dapat dilihat pada Tabel 2. Identifikasi indikator degradasi hutan di lapangan dapat menggunakan peubah yang koefisien determinasinya diatas 60\%. Indikator kerapatan tegakan diameter > $5 \mathrm{~cm}$ yang mempunyai koefisien determinasi di atas 60\% adalah peubah VCR dan kerapatan kanopi sehingga peubah ini dapat digunakan sebagai indikator identifikasi degradasi hutan.

Tabel 2.

Hasil Analisis Regresi antara Kerapatan Tegakan Hidup dan Luas Bidang Dasar dengan Peubah LAI, CSI, CDI, VCR, Kerapatan Kanopi

\begin{tabular}{|c|c|c|c|c|c|c|c|}
\hline \multirow{3}{*}{ No } & \multirow{3}{*}{ Peubah } & \multicolumn{6}{|c|}{ Koefisien Determinasi } \\
\hline & & \multicolumn{3}{|c|}{ Kerapatan Tegakan } & \multicolumn{3}{|c|}{ Lbds } \\
\hline & & $\begin{array}{c}\text { Diameter } \\
>5 \mathrm{~cm}\end{array}$ & $\begin{array}{c}\text { Diameter } \\
>10 \mathrm{~cm}\end{array}$ & $\begin{array}{c}\text { Diameter } \\
>20 \mathrm{~cm}\end{array}$ & $\begin{array}{c}\text { Diameter } \\
>5 \mathrm{~cm}\end{array}$ & $\begin{array}{c}\text { Diameter } \\
>10 \mathrm{~cm}\end{array}$ & $\begin{array}{c}\text { Diameter } \\
>20 \mathrm{~cm}\end{array}$ \\
\hline 1 & LAI & 0.51 & 0.38 & 0.37 & 0.45 & 0.41 & 0.36 \\
\hline 2 & CSI & 0.58 & 0.58 & 0.79 & 0.55 & 0.53 & 0.45 \\
\hline 3 & CDI & 0.58 & 0.57 & 0.66 & 0.43 & 0.39 & 0.31 \\
\hline 4 & VCR & 0.63 & 0.62 & 0.80 & 0.54 & 0.51 & 0.42 \\
\hline 5 & Kerapatan Kanopi & 0.67 & 0.49 & 0.59 & 0.52 & 0.46 & 0.57 \\
\hline
\end{tabular}

Berdasarkan uji T maka variasi kerapatan tegakan diameter $>5 \mathrm{~cm}$ adalah siknifikan mempengaruhi kerapatan kanopi dengan T hitung yaitu 2.4 lebih tinggi dari T tabel 1.96. Pada peubah VCR juga mempunyai T hitung lebih tinggi yaitu 2.24. Hasil analisis ini akan digunakan untuk pembuatan kelas masing masing peubah untuk diuji akurasinya dengan klasifikasi citra. Klasifikasi masing-masing peubah seperti terlihat pada Tabel 3.

Tabel 3.

Kriteria Klasifikasi Kerapatan Hutan, Lbds, Kerapatan Tegakan, Kerapatan Kanopi Hutan, LAI, dan Indikator Tajuk

\begin{tabular}{lllllllll}
\hline No & Klasifikasi & $\begin{array}{c}\text { Lbds } \\
\mathbf{m} 2 / \mathrm{Ha}\end{array}$ & $\begin{array}{c}\text { Kerapatan } \\
\text { Tegakan }> \\
\mathbf{( N / H a )}\end{array}$ & $\begin{array}{c}\text { Kerapatan } \\
\text { Kanopi (\%) }\end{array}$ & LAI & & \multicolumn{2}{c}{ Indikator Tajuk/Ha } \\
\cline { 7 - 9 } & & & & & & CSI & CDI & VCR \\
\hline 1 & NH & $0-1$ & $0-67$ & $0-10$ & $0-0.57$ & $0-1203$ & $0-70$ & $0-1014$ \\
2 & H1 & $1-14$ & $68-478$ & $11-30$ & $0.59-1.6$ & $1203-2907$ & $701-1899$ & $1014-2678$ \\
3 & H2 & $15-26$ & $479-889$ & $31-50$ & $1.7-2.7$ & $2908-4613$ & $1900-3098$ & $2679-4343$ \\
4 & H3 & $27-38$ & $890-1300$ & $51-70$ & $2.8-3.7$ & $4614-6317$ & $3099-4296$ & $4344-6007$ \\
5 & H4 & $>39$ & $>1301$ & $>71$ & $>3.8$ & $>6318$ & $>4297$ & $>6008$ \\
\hline
\end{tabular}

Keterangan: NH non hutan, $\mathrm{H} 1$ hutan kerapatan sangat rendah, $\mathrm{H} 2$ hutan kerapatan rendah, H3 hutan kerapatan sedang, $\mathrm{H} 4$ hutan kerapatan tinggi.

Hasil klasifikasi FCD, maximum likelihood, fuzzy, dan belief diuji keakuratannya dengan data lapangan yaitu kerapatan kanopi, LAI, crown indicator (CSI, CDI, dan VCR), kerapatan tegakan dan Lbds. Berdasarkan uji akurasi dengan overall accuracy dan analisis Kappa dengan berbagai indikator lapangan maka dapat dilihat pada Tabel 4 . 
SIGIT NUGROHO, I NENGAH SURATI JAYA, M BUCE SALEH, ANTONIUS B WIJANARTO KAJIAN METODE DETEKSI DEGRADASI HUTAN MENGGUNAKAN CITRA SATELIT LANDSAT DI ...

Pada klasifikasi FCD dapat dilihat bahwa akurasi tertinggi untuk klasifikasi kerapatan hutan adalah pada kerapatan kanopi dan kerapatan tegakan diameter $>5 \mathrm{~cm}$. Akurasi kerapatan kanopi yaitu di atas $85 \%$. Pengunaan indikator kerapatan tegakan diameter $>5 \mathrm{~cm}$ mempunyai akurasi sedang yaitu 61\%. Penggunaan indikator LAI, CSI, CDI, VCR, dan Lbds tidak dapat digunakan karena mempunyai akurasi yang rendah.

Tabel 4.

Hasil Uji Akurasi Klasifikasi FCD, Maximum Likelihood, Fuzzy, dan Belief Dempster Shafer

\begin{tabular}{|c|c|c|c|c|c|c|c|c|c|}
\hline \multirow{3}{*}{ No } & \multirow{3}{*}{ Indikator Lapangan } & \multicolumn{8}{|c|}{ Hasil Uji Akurasi (\%) } \\
\hline & & \multicolumn{2}{|c|}{ FCD } & \multicolumn{2}{|c|}{$\begin{array}{c}\text { Maximum } \\
\text { Likelihood }\end{array}$} & \multicolumn{2}{|c|}{ Fuzzy } & \multicolumn{2}{|c|}{ Belief } \\
\hline & & $\begin{array}{c}\text { Overall } \\
\text { accuracy }\end{array}$ & $\begin{array}{l}\text { Koef. } \\
\text { Kappa }\end{array}$ & $\begin{array}{c}\text { Overall } \\
\text { accuracy }\end{array}$ & $\begin{array}{c}\text { Koef. } \\
\text { Kappa }\end{array}$ & $\begin{array}{c}\text { Overall } \\
\text { accuracy }\end{array}$ & $\begin{array}{c}\text { Koef. } \\
\text { Kappa }\end{array}$ & $\begin{array}{l}\text { Overall } \\
\text { accuracy }\end{array}$ & $\begin{array}{l}\text { Koef. } \\
\text { Kappa }\end{array}$ \\
\hline 1 & Kerapatan Kanopi & 86 & 79 & 82 & 74 & 73 & 59 & 65 & 49 \\
\hline 2 & LAI & 53 & 39 & 47 & 32 & 43 & 26 & 51 & 35 \\
\hline 3 & CSI & 59 & 44 & 51 & 36 & 45 & 27 & 39 & 20 \\
\hline 4 & CDI & 60 & 47 & 56 & 38 & 58 & 38 & 47 & 30 \\
\hline 5 & VCR & 59 & 40 & 59 & 40 & 55 & 35 & 51 & 32 \\
\hline 6 & $\begin{array}{l}\text { Kerapatan Tegakan } \\
\mathrm{d}>5 \mathrm{~cm}\end{array}$ & 61 & 46 & 57 & 40 & 51 & 34 & 49 & 32 \\
\hline 7 & Lbds $d>5 \mathrm{~cm}$ & 30 & 14 & 43 & 30 & 49 & 36 & 47 & 32 \\
\hline
\end{tabular}

Pada klasifikasi maximum likelihood maka klasifikasi kerapatan hutan mempunyai akurasi sedang yaitu $82 \%$ pada indikator kerapatan kanopi. Penggunaan indikator LAI, CSI, CDI, VCR, dan Lbds tidak dapat digunakan karena mempunyai akurasi yang rendah. Penggunaan klasifikasi fuzzy mempunyai akurasi sedang pada indikator kerapatan kanopi yaitu $73 \%$, sedangkan pada indikator lainnya adalah rendah. Berdasarkan akurasinya maka klasifikasi kerapatan hutan menggunakan klasifikasi fuzzy dan maximum likelihood kurang baik digunakan.

Klasifikasi belief kurang baik digunakan untuk klasifikasi kerapatan hutan. Akurasi klasifikasi ini menunjukkan bahwa akurasinya di bawah $60 \%$ untuk semua indikator lapangan kecuali indikator kerapatan kanopi. Akurasi tertinggi hanya didapatkan pada indikator kerapatan kanopi 65\%. Penggunaan indikator kerapatan hutan lainnya diantaranya LAI, CSI, CDI, VCR, dan Lbds mempunyai akurasi yang rendah.

Berdasarkan analisis regresi data lapangan maka identifikasi degradasi hutan dengan indikator kerapatan tegakan diameter $>5 \mathrm{~cm}$ dapat menggunakan peubah kerapatan kanopi dan VCR. Oleh karena itu, maka tingkat degradasi dapat diklasifikasikan seperti pada Tabel 5 .

Tabel 5 .

Klasifikasi Tingkat Degradasi Hutan

\begin{tabular}{|c|c|c|c|c|}
\hline \multirow[b]{2}{*}{ No } & \multirow{2}{*}{$\begin{array}{l}\text { Tingkat } \\
\text { Degradasi }\end{array}$} & \multicolumn{3}{|c|}{ Pengurangan } \\
\hline & & $\begin{array}{c}\text { Kerapatan tegakan }(\mathrm{N} / \mathrm{Ha}) \mathrm{d} \\
>5 \mathrm{~cm}\end{array}$ & Kerapatan Kanopi (\%) & $\begin{array}{c}\text { Indikator Tajuk } \\
\text { VCR/Ha }\end{array}$ \\
\hline 1 & Ringan & $6-416$ & $1-20$ & $265-1929$ \\
\hline 2 & Sedang & $417-826$ & $21-40$ & 1930-3594 \\
\hline 3 & Berat & $827-1237$ & $41-60$ & $3595-5258$ \\
\hline 4 & Sangat Berat & $>1238$ & $>60$ & $>5259$ \\
\hline
\end{tabular}


Berdasarkanhasilujiakurasiklasifikasi maka metode yang mempunyai akurasi di atas $85 \%$ adalah klasifikasi FCD. Oleh karena itu, maka dapat disimpulkan bahwa metode klasifikasi yang dapat digunakan untuk uji akurasi deteksi degradasi hutan adalah menggunakan metode tersebut. Berdasarkan uji akurasi dengan data lapangan yaitu kerapatan kanopi, crown indicator (CSI, CDI, dan VCR), kerapatan tegakan, LAI, dan Lbds maka overall accuracy yang terbaik adalah pada indikator kerapatan kanopi dan kerapatan tegakan diameter $>5 \mathrm{~cm}$.

Akurasi deteksi degradasi hutan menggunakan klasifikasi FCD dengan indikator pengurangan kerapatan tegakan diameter $>5 \mathrm{~cm}$ secara temporal dari tahun 2003 sampai 2008 dapat dilihat pada Tabel 6.

Tabel 6.

Hasil Uji Akurasi Tingkat Degradasi Hutan di Lapangan dengan Klasifikasi FCD

\begin{tabular}{lllc}
\hline & Indikator & \multicolumn{2}{c}{ FCD } \\
\cline { 3 - 4 } No & Lapangan & $\begin{array}{c}\text { Overall } \\
\text { Accuracy } \\
\mathbf{( \% )}\end{array}$ & $\begin{array}{c}\text { Koefisien } \\
\text { Kappa } \\
\mathbf{( \% )}\end{array}$ \\
11 & $\begin{array}{l}\text { Kerapatan } \\
\text { tegakan d } \\
\text { iameter }>5 \mathrm{~cm} \\
\text { (tunggak) }\end{array}$ & 68 & 54 \\
\hline
\end{tabular}

Metode terbaik untuk deteksi degradasi hutan adalah dengan menggunakan klasifikasi FCD. Hasil klasifikasi FCD tersebut digunakan untuk menghitung luas degradasi hutan. Tabel 7 menunjukkan mengenai luas degradasi hutan dari tahun 2003 sampai 2008.
Pada Tabel 7 dapat dilihat bahwa total degradasi hutan dari tahun 2003 sampai 2007 yaitu seluas $1080 \mathrm{Ha}$. Persentase terbesar degradasi hutan terlihat pada kelas degradasi ringan yaitu 18\%. Persentase degradasi berat sangat kecil yaitu $1 \%$. Hal ini dapat disimpulkan bahwa penebangan kayu pada kawasan ini terjadi tidak secara tebang habis, tetapi hanya tebang pilih secara sporadis. Total degradasi hutan dari tahun 2007 sampai 2008 yaitu seluas 284 Ha. Persentase terbesar degradasi hutan terlihat pada kelas degradasi ringan yaitu 5\%. Persentase degradasi berat sangat kecil yaitu $0,6 \%$.

\section{SIMPULAN}

1. Deteksi degradasi hutan menggunakan citra landsat dapat menggunakan indikator kerapatan tegakan diameter di atas $5 \mathrm{~cm}(\mathrm{~N} / \mathrm{Ha})$.

2. Tingkat akurasi klasifikasi kerapatan hutan menggunakan indikator kerapatan tegakan diameter di atas $5 \mathrm{~cm}$ yang paling tinggi dari empat metode adalah menggunakan metode FCD yaitu dengan overall accuracy sebesar $61 \%$ dan koefisien kappa 46\%. Tingkat akurasi klasifikasi menggunakan metode maximum likelihood yaitu overall accuracy $57 \%$ dan koefisien kappa 40\%. Metode fuzzy mempunyai tingkat akurasi dengan overall accuracy $51 \%$ dan koefisien kappa 34\%. Metode belief-dempster shafer mempunyai tingkat akurasi overall accuracy $49 \%$ dan koefisien kappa 32\%.

Tabel 7.

Luas Degradasi Hutan Tahun 2003-2008

\begin{tabular}{cccccc}
\hline No & Kelas & \multicolumn{3}{c}{$2003-2007$} & \multicolumn{2}{c}{$2007-2008$} \\
\cline { 3 - 6 } & Degradasi & Luas Ha & \% Total Wilayah & Luas Ha & \% Total Wilayah \\
\hline 1 & Ringan & 766 & 18 & 231 & 5 \\
2 & Sedang & 266 & 6 & 49 & 2 \\
3 & Berat & 48 & 1 & 4 & 0 \\
\hline & Jumlah & 1080 & 26 & 284 & 7 \\
\hline
\end{tabular}


SIGIT NUGROHO, I NENGAH SURATI JAYA, M BUCE SALEH, ANTONIUS B WIJANARTO * KAJIAN METODE DETEKSI DEGRADASI HUTAN MENGGUNAKAN CITRA SATELIT LANDSAT DI ...

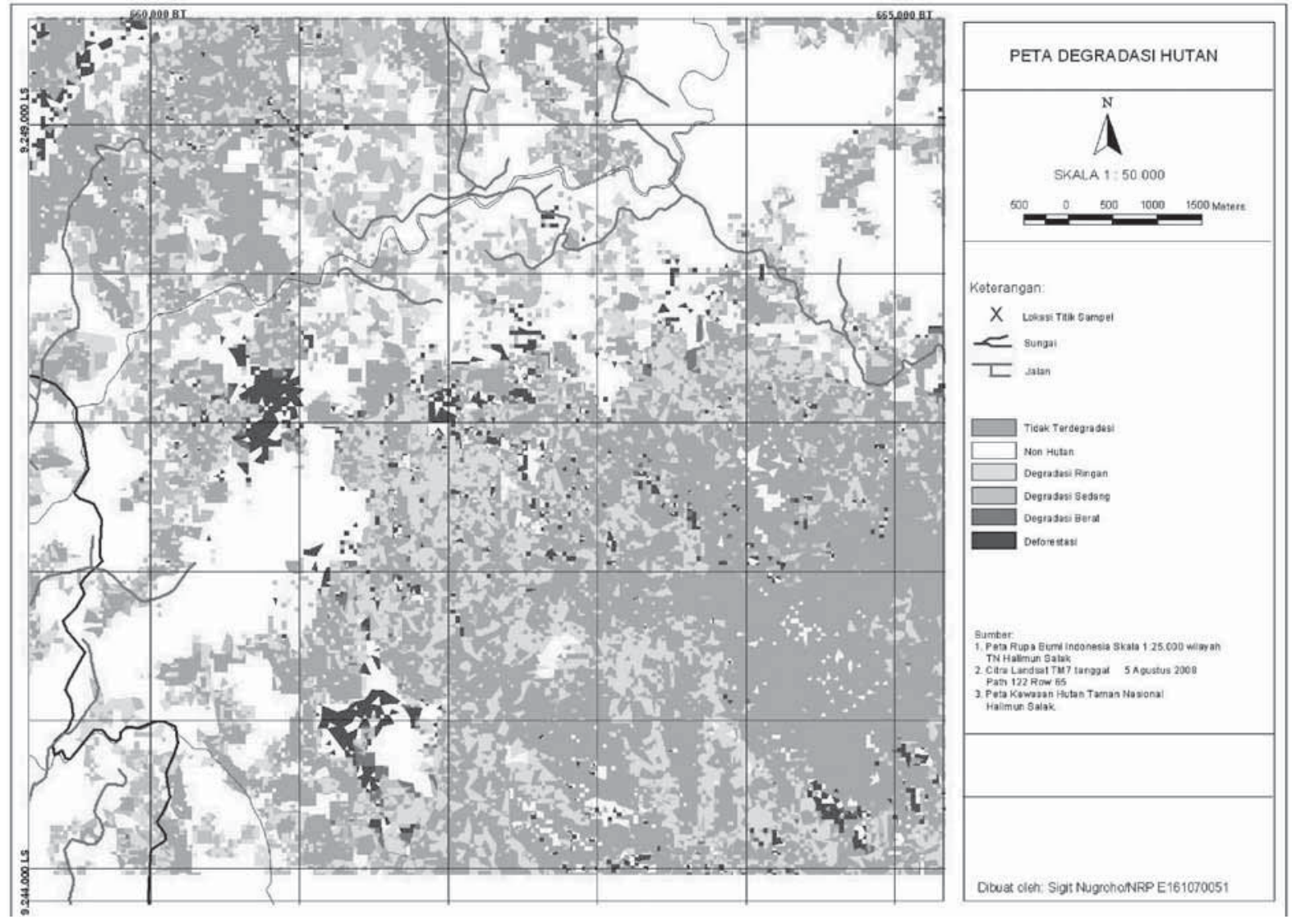

3. Berdasarkan tingkat akurasi deteksi degradasi hutan menggunakan indikator kerapatan tegakan maka metode yang terbaik adalah klasifikasi FCD dengan overall accuracy $68 \%$ dan koefisien kappa $54 \%$.

\section{DAFTAR PUSTAKA}

Bahamondez et al., 2009, An Operational Approach to Forest Degradation, Forest Degradation Meeting FAO Rome 8-9 September 2009. Hlm 1-34.

Defries R et al., 2007, Earth Observations for EstimatingGreenhouseGasEmissions from Deforestation in Developing Countries, J Environmental Science and Policy 10: 385-394.

Departemen Kehutanan, 2008, Perhitungan Deforestasi Indonesia Tahun 2008, Jakarta: Departemen Kehutanan Republik Indonesia.
Food and Agriculture Organization's, 2005, Forest Resources Assessment 2005 Update 2005; Terms and Definition, Rome: FRA Programe

Hadi F, Wikantika K, Sumarto I, 2004, Implementation of Forest Canopy Density Model to Monitor Forest Fragmentation in Mt. Simpang and Mt. Tilu Nature Reserves, West Java, Indonesia. Indonesian FIG Regional Conference 3-7 Oktober 2004.

Hwan O.M dan Merlinda R.M, 2008, Forest Canopy Density Mapping For Forest Climate Change Mitigation/REDD Activities. Japan-Asia REDD Seminar, 24-25 Maret 2008.

Joshi C. et al., 2006, Remotely Sensed Estimation of Forest Canopy Density: a Comparison of the Performance of Four Methods. Int. J. Applied Earth Observation and Geoinformation 8:84-94. 


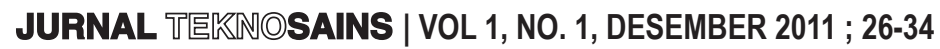

Kanninen et al., 2009, Apakah Hutan dapat Tumbuh di atas Uang. Implikasi penelitian Deforestasi bagi Kebijakan yang Mendukung REDD. Perspektif Kehutanan 4:1-55. Bogor: CIFOR

Murdiarso D. et al., 2008, Measuring and monitoring Forest Degradation for REDD, Implications of Country Circumstances. Bogor:Info Brief Cifor Vol.16.

Panta M, Kim K, Joshi C, 2008, Temporal Mapping of Deforestation and Forest Degradation in Nepal: Applicatons to Forest Conservation, J. Forest Ecology and Management 256:1587-1595.
Penman J et al., 2003, Good Practice Guidance for Land Use, Land-Use Change and Forestry, IPCC National Greenhouse Gas Inventories Programme and Institute for Global Environmental Strategies (IGES), Kanagawa, Japan. Intergovernmental Panel on Climate Change. http://www.ipcc-nggip. iges.or.jp/ public/gpglulucf/ gpglulucf_contents.htm. [ 3 Maret 2010].

Rikimaru A, 2003, Concept of FCD Mapping Model and Semi-Expert System, Japan: Overseas Forestry Consultants Association. 